\title{
Кисляк Ю.Ф. \\ Особенности структуры учебной мотивации в условиях вузовского обучения
}

Современные условия жизни предъявляют новые требования к рынку образовательных у слуг. В высших учебных заведениях происходит переход на новые модели обучения, существенно изменяются учебные планы, вводятся новые специальности и курсы, формы организации занятий, внедряются новые педагогические технологии, образовательные стандарты.

Проблема мотивации различных видов деятельности (в том числе и учебной) является одной из наиболее разрабатываемых в современной педагогической психологии, оставаясь при этом одной из наиболее сложных и актуальных, что связано с многогранностью и многоаспектностью такого явления, как мотив. Мотивация любой деятельности имеет сложную, многоуровневую систему и учебная мотивация не является исключением.

Большинство исследователей проблемы учебной мотивации (В.Д. Шадриков, Д.Б. Эльконин, В.В. Давыдов, О.С. Гребенюк, А.К. Маркова) сходятся во мнении, что учебная мотивация - это общее название для процессов, методов, средств побуждения обучаемых к продуктивной познавательной деятельности, активному освоению содержания образования. У чебная мотивация позволяет развивающейся личности определить не только направление, но и способы реализации различных форм учебной деятельности, задействовать эмоционально-волевую сферу. Она выступает значимой многофакторной детерминацией, обуславливающей специфику учебной ситуации в каждый временной интервал [1].

Анализ отечественных психологических исследований по проблеме мотивации учебной деятельности показал наличие целого спектра концепций структуры мотивации учебной деятельности. Наиболее распространенными можно назвать:

- концепцию социальных и познавательных типов мотивов обучения (Л.И. Божович, Н.Г. Морозова, Л.С. Славина): широкие социальные мотивы у чения и познавательные мотивы, т.е. непосредственно связанные с содержанием учебной деятельности. Оба типа мотивов - социальные и познавательные являются существенно необходимыми для побуждения деятельности у чения [2].

- концепция внешней и внутренней мотивации (П.Я. Гальперин, П.М. Якобсон, В.Ф. Моргун, В.И.Чирков и др.). Внешняя мотивация не связана с самой учебной деятельностью, активность обучаемого в этом случае направлена на отношения с другими людьми, на определение своего положения в коллективе и так далее, то есть смысл и значение приобретает не сама деятельность, а только то, что связано с ней. Внутренняя мотивация порождается самой учебной деятельностью, обеспечивает активность у ченика в познании нового, в овладении способами приобретения знаний [2]. 
Сравнительный анализ особенностей структуры учебной мотивации школьников и структуры учебной мотивации студентов вузов выявил ряд специфических особенностей. Так, в целом ряде исследований было показано, что на изменение мотивов учебной деятельности студентов оказывает влияние профессиональной профиль вуза, половозрастные, интеллектуальные и личностные особенности студентов, уровень и степень включения студентов в учебную деятельность.

Специфические особенности структуры учебной мотивации студентов были выявлены, в частности, при сопоставлении мотивов у чения студентов государственных и негосударственных вузов (М.Г. Рогов, М.М. Соколова, О.В. Гаврилова, Л.Р. Яруллина). Они обнаружили, что у студентов негосударственных вузов преобладают социальные мотивы у чения (выбор престижной специальности, получение «признаваемого» диплома и т.д.). [3]

Исследования О.А. Чаденковой [4] показали, что у студентов технических вузов в среднем уровень мотивации учебной деятельности выше, чем у студентов гуманитарных вузов.

Особое место в ряду изучения мотивов учебной деятельности студентов, занимают исследования учебной мотивации курсантов и студентов вузов казарменного положения. Специфической особенностью данных вузов является то , что учебный процесс не является единственным видом деятельности курсантов. Он тесно связан с выполнением курсантами служебных обязанностей (наряды, вахты), и с первого года обучения курсанты и студенты являются включенными в процесс постижения азов выбранной профессии, будучи максимально приближенными к реальным условиям жизни после окончания вуза. Несмотря на это обстоятельство, исследования Б.В. Илькевича, В.А. Поломаренко, В.В. Болдырева, И.Ю. Анашкина [5] показало, что у многих курсантов интерес к выбранной профессии и обучению в военном институте оказался временным и неустойчивым и во время обучения общая и военно-профессиональная мотивация угасает у 56\% курсантов 1-4 курсов.

Важно отметить, что структура мотивации учебной деятельности у курсантов военных учебных заведений не является статичным образованием, а изменяется в течение срока обучения. И.И. Бринько [6], выявил, что динамика структуры мотивации обучения курсантов отличается от данных, полученных в условиях гражданских вузов: во-первых, поляризацией внутренних мотивационных ориентации (на результат и на процесс), а, во-вторых, стабильным повышением интенсивности мотивационной ориентации на избегание неприятностей.

По мнению Мамаевой Н.А «..модель формирования учебной мотивации студентов вузов обладает следующими признаками: активность (способность модели преобразовывать объект с учетом внешних и внутренних условий); целенаправленность; системность (система, состоящая из компонентов: цели, содержания, дидактических процессов, средств организации деятельности; контингент участников и организаторов деятельности); структурность (состоит из компонентов, взаимосвязанных между собой); динамичность (дает возможность 
отслеживать происходящие изменения на различных этапах процесса); гибкость (допускает изменения в организации в случае изменения условий происходящего процесса); последовательность (переход с одного этапа на другой, каждый из которых в свою очередь содержит ряд последовательных мероприятий по формированию учебной мотивации студентов вузов); управляемость (модель управляема со стороны организаторов процесса формирования учебной мотивации студентов вузов)» [7].

В результате проведенного теоретического анализа проблемы мотивации учебной деятельности в высшей школе можно сделать следующие выводы.

1. Мотивация учебной деятельности в ВУЗе - это сложный психологический феномен, управление которым в учебном процессе требует у чета его структурной организации, динамичности.

2. Учебная мотивация характеризуется сложной структурой, одной из форм которой является структура внутренней (на процесс и результат) и внешней (награда, избегание) мотивации.

3. Факторы, оказывающие влияние на структуру учебной мотивации, являются достаточно разноплановыми и разноуровневыми (пол, возраст обучающихся, их личностно-когнитивные особенности, форма и профиль обучения и др.)

\section{Литература:}

1. Мерлин В.С. Структура личности: характер, способности, самосознание: У ч. пособие. - Пермь: ПГПИ, 1990.

2. Бибрих Р.Р., Васильев И.А. Особенности мотивации и целеобразования в учебной деятельности студентов младших курсов//Вестник Московского университета. Серия 14. - 1987. - № 2. - С. 20-30.

3. Яруллина Л.Р. Ценностные ориентации студентов негосударственных высших учебных заведений//Прикладная психология. - 2002. - № 5/6. - С. 140-144.

4. Чаденкова О.А. Изучение и формирование мотивации учебной деятельности студентов// Теория и методика непрерывного профессионального образования. Материалы докладов Всерос. научно-методич. конференции. - Тольятти: ТГУ, 2002. Том 2. - С. 176-179.

5. Илькевич Б.В., Поломаренко В.А., Болдырев В.В., Анашкин И.Ю. Профессиональная и учебная мотивация курсантов ПВО //Университетское образование и регионы: Тезисы докладов международной научно-методической конференции. - Пермь. 2001. - С. 348.

6. Бринько И.И. Особенности формирования мотивации учебной деятельности курсантов военного вуза. - Вестник ИВШ МВД России. - 1997. - № 1. - С. 67-73.

7. Мамаева Н.А. Формирование учебной мотивации студентов технических вузов. Автореф. дисс. канд. пед. наук. - Великий Новгород. 2007. -22 с. 